\title{
Privacy and Social Media
}

\section{Conceptual Review on Private Turbulence in Communication Privacy Management of Social Media}

\author{
Monika Sri Yuliarti, Likha Sari Anggreni, Prahastiwi Utari \\ Dept. of Communication \\ Universitas Sebelas Maret \\ Surakarta, Indonesia \\ monika.yuliarti@staff.uns.ac.id
}

\begin{abstract}
The shift of the era produces some new innovations. When it comes to the global era, internet seems crucial in creating people's new way of life. Communication process also changes along with the invention of the internet, which also possible to be done in social media. Meanwhile, human interaction involves privacy management issues, with private turbulence as one of its aspects. The aim of this study is to reveal the conceptual framework of private turbulence in the context of communication using social media. Communication privacy management theory from Sandra Petronio will be employed as the main theory in this study. It is a qualitative descriptive study, with literature/ document study as the technique for gaining the data. The expected finding of this study is a conceptual framework of private turbulence in communication using social media that can be applied in some cases that involve new media.
\end{abstract}

Keywords-privacy; social media; private turbulence; communication private communication privacy

\section{INTRODUCTION}

Technology requires adjustment in society. The innovation that comes from a new technology cannot end in the finding of the product, because the scholars also need to think about the implementation of the innovation among the people. Ogburn's theory of social change explained that the cause of social change is technology. It is clear that from the research of Mutekwe [1], it can be shown that there was an increasing complexity of social life due to the technology, including the social movement in the society. By affecting the society, it is also affecting the culture, the way of people life. It can be seen as a threat, where some technologies change people's role in work matter, for example. However, technology also creates a cultural diffusion, cultural leveling, globalization and the information superhighway.

Another impact of technology in society also involves human interaction style, especially in the shift of face to face communication to mediated communication. It is found that, in the research among Elon University concluded that both of the quality and quantity of face-to-face communication has affected negatively by the technology. There was a less awareness on face to face interaction, and it gets higher even with the presence of other [2]. The finding told us that direct communication no longer dominates human interaction among the students. Furthermore, it could affect the way of human relations. By doing direct communication, two people will have to be at the same time and exchanging the messages. However, as the technology comes, the process of exchanges not only can be done in direct way but also in indirect way, that involves a channel.

Indirect human communication that happens using a channel has already been researched in some aspects, such as the purpose [3], the effect [4], and the effectiveness [5]. These researches show that doing indirect communication gives the benefit for human's life. However, the less direct interaction that caused by it also need to be paid attention to. Interpersonal communication that is being done in direct way can be done as linear, interactional, and transactional model [6]. The differences of three models lie in the flow of the communication. Linear communication is a one-way communication, so there is no feedback appears in this model, while interactional model involves a feedback, so that it can be called as two ways of communication. The third model, transactional contains of the multiple flow of interactional model. Moreover, indirect interpersonal communication, or some experts may call it as computer-mediated communication, also can be done in those three models. The difference of them is the using of the channel. In computer mediated communication, the exchanging messages be done using a channel, it is communication software application like instant messaging application or social media.

In the meantime, privacy becomes a prominent issue among human relations, since it is one of the human rights based on Universal Declaration of Humans Right. In article 2 it is stated: "No one shall be subjected to arbitrary interference with his privacy, family, home or correspondence, nor to attacks upon his honor and reputation. Everyone has the right to the protection of the law against such interference or attacks." [7]. From the article, it can be understood that privacy is part of humans right that is protected by law. Therefore, violate it must have caused negative impact.

The violation of someone privacy may happens during the interaction in the process of communication. It means that, it is possible occurs in direct and indirect communication, either face to face communication or computer mediated communication. Therefore, it is important to know how to manage the privacy. By the changing of the era, it is important 
to understand the phenomenon that also may take place in different form, so it is crucial to understand one of the concepts in the issue of privacy management, it is private turbulence.

\section{LITERATURE REVIEW}

\section{A. Interpersonal Communication vs Computer Mediated Communication}

Communication is crucial in human's life. When a first time of a life, a baby was born to this world, they did communication. Crying is classified to nonverbal communication since it is involved a sound. Along the times, communication also is needed even for fulfilling the basic human needs. As a social creature, human also need to communicate with each other, and they will need another person as part of their life.

Academically, communication is not only about speaking and interacting with others but is a greater meaning. Fiske [8] explains that there are two schools of communications, the first school says that communication is the transmission of message and the second school sees communication as the production and exchange meaning. In relations to the interpersonal communication, the first school is more appropriate.

Interpersonal communication is not only about the number of participants involved in a communication process [9], but also some aspects that affect it [6]. Trenholm and Jensen in [9] define interpersonal communication as communication between two people that take place face to face (dyadic communication). Characters of interpersonal communication are spontaneous and informal; involve a maximum feedback between the participants; and the participants' role is flexible. Meanwhile, Wood [6] decided to define interpersonal communication by exploring the characteristics of it; they are selective, systemic, unique, processual, transactional, individual, personal knowledge, and meaning creating. All of the characteristics can help us to decide how to define the term so that we can get a precise explanation about interpersonal communication.

Meanwhile, computer mediated communication involves exchanges of information in the format of text, audio, and/or video. They carried and controlled by the use of computer and telecommunication technology. December in [10] defines computer mediated communication as a process of human communication vie computers, involving people, situated particular contexts, engaging in process to shape media for a variety of purpose. From the definition it can be learned that computer mediated communication can be done using a particular channel.

In [11] computer mediated communication is explained in term of the feature of the message. Walther said that computer mediated communication contained of text-based messages. Since it is written text, it filters out most nonverbal cues that may help supporting the meaning of a sentence. It was the early 1990's when the first-time computer mediated communication was established and employed by many people. It might be fine for task-related purposes such as information processing, news dissemination, and long-distance conferencing. But as a place to interact and bond with others, cyberspace seemed to be a relational wasteland.
Computer mediated communication in terms of research can be studied in the level of interpersonal and also mass communication. In the context of this research, computer mediated communication in interpersonal communication is the focus.

\section{B. Social Media}

Social media has a close relation to the technology. What many people call "new" communication technologies are actually extensions and convergences of communication technologies that have been around for some time. Convergence of technologies radically alters how people do business, engage in research, share information and ideas, and sustain personal relationships. The key word for the future of communication technologies is interconnectivity, which promises to be good news for people who are not tech savvy. Interconnectivity is the connecting of various devices to each other and to the Internet so users don't have to independently configure each new system. For instance, before cell phone, technologies of telephone and PC are separated [12].

Since internet becomes the crucial part of the communication technology, one of the innovation in it also crucial in people's life nowadays, it is social media. Social media is a medium in the internet that enables the users to interact, cooperate, share, and communicate, and form a social bond virtually [13]. It can be also understood as a group of new kinds of online media with participation, openness, conversation, community, and connectedness characteristics [14].

Studies about social media have been doing by some researchers. Some of them are about the effect of social media [15]-[16] and the general use of social media [17]. Many people believe that social media has negative effect in people's life. This opinion mostly based on the social phenomena that show the negative effect on it, such as cyber-bullying, causing less direct social interaction among humans, increase the ignorance among people and so forth. However, social media just like any other innovation that always has positive and also negative effect.

\section{Private Turbulence in Communication Privacy Management}

Privacy is linked to self-disclosure because notions of privacy affect individuals if, how, and when they self disclose information [18]. Meanwhile, Petronio in [19] suggested that privacy is 'the feeling that one has the right to own private information either personally or collectively. In communication study, there is a theory, called Communication Privacy Management Theory from Sandra Petronio that governs it [20]. It is seen as a map of the way people navigate privacy. Petronio wants us to think of privacy boundaries that encompass information we have but others don't know. Privacy boundaries can be varied from thin and porous filters to thick, impenetrable barriers that shield deep, dark secrets. But whenever we share a portion of that information with someone, we are reshaping a privacy boundary. Having a mental image of protective boundaries is central to understanding the five core principles of Petronio's CPM [20]. The principles are: (1) 
People believe they own and have a right to control their private information; (2) People control their private information through the use of personal privacy rules; (3) When others are told or given access to a person's private information, they become co-owners of that information; (4) Co-owners of private information need to negotiate mutually agreeable privacy rules about telling others; (5) When coowners of private information don't effectively negotiate and follow mutually held privacy rules, boundary turbulence is the likely result.

Moreover, Littlejohn, Foss, and Oetzel [21] propose the model of communication privacy management element that consists of three big parts. The elements are (1) privacy ownership; (2) privacy control; and (3) privacy turbulence. The elements able to give clearer information about how the privacy management works in human communication, after get the information about principle of managing privacy.

Privacy turbulence happens when someone as a co-owner of a private information faces the fact that boundary rules are sometimes ambiguous. Agreement not always there, so sometimes there is a violation upon it [21]. In real life private turbulence may happen when someone accidently reveal a secret when they are having a gossiping session with others.

\section{METHODS}

It is a qualitative descriptive research, where the condition, process, and the connection of important aspects that found in the phenomena and be studied are described here. Interpretation is hardly needed to gain the fruitful finding [22]. The collecting data technique employed in this research is documentary study or literature study, where the source of the data is written, either printed or online version [23]. The documents and literature that were used in this research were the references about interpersonal communication, computer mediated communication, social media, and communication privacy management.

Moreover, the data analysis technique in this research is inductive analysis. Therefore, in this research, the data analysis was done together with the process of collecting data, not after the collecting data has finished. It was beneficial in term of meeting the complete finding, so that the collecting data still can be done if there was a shortage of the data [24].

The process of analysis data in this research can be divided into two parts. The first is the literature study in the interpersonal communication, computer mediated communication, social media, and communication privacy management. Then, it is followed by the elaboration on the characteristic of social media interaction and the communication privacy management.

\section{RESULT AND DISCUSSION}

The change of interaction among human has consequences to check on the application of some theories in a particular level of communication. Privacy as part of human interaction nowadays lies in different form of communication. Interpersonal communication that is involved in the privacy issue, especially in the privacy management, may happens in the interpersonal communication that happens using a channel. The appearance of social media that start to dominates human interaction nowadays may resulted a need to manage the privacy in term of social media communication.

Checking on the model of communication management privacy theory is the easiest way to understand it in the online communication application. As mentioned earlier, privacy ownership, privacy control, and privacy turbulence are the parts of communication management privacy model [21]. This paper only concern to the last part of the model. Hence, the explanation is needed to be done from the first part.

The privacy ownership refers to who owns the information about the person [21]. It is not only the person who has the information about themselves (the original owner), but also the second party that has shared information because the original owner reveals them (the co-owner). Either the original owner or the co-owner of the private information is the owners of the information. When it comes to become the co-owner, they have to play the rule as same as the original owner where lead us to the second element, privacy control.

Moreover, privacy control is the negotiation among the owners of a private information about the rule that involved in a private information, in order to keep and manage the information [21]. Thus, this element has a strong relation with the boundary issue, or as Petronio says it consists of rule-based boundary management. Study about communication management privacy mostly has done in health issue as well as boundary management. McAloon [25] concluded that privacy boundaries mark the limits of how much private information someone is willing to reveal. It could be made more or less permeable depending on motivation. In the study it is found that the boundaries however seem to be more open when a person who has a visible disability is talking to someone else who has a visible disability. The reason for participants to allow information to flow freely is because they feel more at ease and share a common identity with someone who has a visible disability.

The third element is privacy turbulence. It is a condition where the owners of a private information lose control in the second element mentioned above [21]. It may have harmed by self-disclosure since ambiguity rules and violations of rules are part of this element. Chennamaneni \& Taneja [26] found that self-disclosure plays an important role in term of privacy turbulence. Their research shows that self-disclosure on social media is particularly rewarding in terms of forming and fostering relationships, building social capital and managing identity.

In the context of social media, there will be some differences in privacy turbulence that might happen in term of privacy information. It is because social media is classified to computer mediated communication, that hold special characteristics, such as contained of text-based messages [11]. Therefore, the form of the privacy turbulence can be found in written verbal and nonverbal communication. Words, Sentences, and narrative story are the example of the written verbal communication in social media. Meanwhile, nonverbal communication can be seen in the use of picture, image, or emoji in the social media. 
Moreover, looking at the characteristic of the social media itself, may give insights in term of the form of privacy turbulence. Since social media is a group of new kinds of online media with participation, openness, conversation, community, and connectedness characteristics [14], each of the characteristic can be explained in the context of privacy information issue. Privacy turbulence may happen wider and faster than in human communication because everyone can be participated in the conversation. Once it is reveal, then the effort to stop the wider spread will be useless.

\section{CONCLUSION}

Privacy turbulence is one of the three key elements of communication privacy management. It is also happening in social media communication. The model of communication privacy management in human communication can also be applied in the context of social media communication. Privacy turbulence in social media communication also consists of ambiguity of rules and violation of rules, just as the privacy turbulence in human communication. The difference is the form of the process of privacy turbulence happens. Since communication in social media is a computer mediated communication, the format will be dominated by written verbal and nonverbal communication, while in human communication, the format is spoken verbal a nonverbal communication.

\section{ACKNOWLEDGEMENT}

This research is funded by the grant of PNBP (Penerimaan Negara Bukan Pajak/ Non-Tax Government Revenue) from Universitas Sebelas Maret, Surakarta, Indonesia, under the scheme of Hibah Penelitian Fundamental 2018.

\section{REFERENCES}

[1] E. Mutekwe, "The Impact of Technology on Social Change: A Sociological Perspective", in Journal of Research, Gender, and Development, Vol. 2 (1), 2012, pp. 226-23.

[2] E. Drago, "The Effect of Technology on Face-to-Face Communication", in The Elon Journal of Undergraduate Research in Communications, Vol. 6, No. 1, Spring 2015, pp. 13-19.

[3] B.S. Argasona and M.S. Yuliarti, Aplikasi Instant Messaging dan LDR (Studi Deskriptif Penggunaan Aplikasi LINE pada Mahasiswa S1 FISIP UNS Angkatan 2014 - 2015 yang Menjalani Long Distance Relationship (LDR) untuk Menyelesaikan Konflik), in Jurnal Komunikasi Massa, vol.1, 2017, from http://www.jurnalkommas.com/docs/JURNAL\%20BIMA\%20SANDRI A\%20ARGASONA_D0213022.doc., accessed in February 21, 2018.

[4] H.F. Arifin, Pengaruh Whatsapp terhadap Perilaku Tertutup Mahasiswa (Survey pada Mahasiswa Ilmu Komunikasi FISHUM Universitas Islam Negeri Sunan Kalijaga Yogyakarta Angkatan 2014), Skripsi, UIN SUNAN Kalijaga Yogyakarta, 2014

[5] C. Barhoumi, "The Effectiveness of WhatsApp Mobile Learning Activities Guided by Activity Theory on Students' Knowledge Management", in Contemporary Educational Technology, 2015, vol 6 (3), pp. 221-238.

[6] J.T. Wood, Interpersonal Communication: Everyday Encounters Sixth Edition, Boston, MA: Wadsworth, 2010.

[7] United Nations, Universal Declaration of Human Rights, retreived from http://www.ohchr.org/EN/UDHR/Documents/UDHR_Translations/eng.p df., accessed in February 20, 2018.

[8] J. Fiske, Introduction to Communication Studies Second Editions, London: Taylor \& Francil e-Library, 2002.
[9] S. Aw, Komunikasi Interpersonal, Yogyakarta: Graha Ilmu.

[10] G. Bubas, Computer mediated communication theories and phenomena: Factors that influence collaboration over the internet, submitted for the 3rd CARNet Users Conference, Zagreb, September 24-26, 2001.

[11] J. Walther, "Social Information Processing Theory", in A First Look at Communication Thoery Eight Edition, E.M. Griffin (Eds). New York: Mc-Graw Hill, 2012, pp. 138-150.

[12] J.T. Wood, Communication Mosaics: An Introduction to The Field of Communication, Boston, MA: Wadsworth, 2011

[13] R. Nasrullah, Media Sosial: Perspektif Komunikasi, Budaya, dan Sosioteknologi. Bandung: Simbiosa Rekatama Media, 2015.

[14] A. Mayfield, What is social media? In "E-book from ICrossing". Retrieved from http://www.icrossing.com/uk/sites/default/files_uk/insight_pdf_files/Wh at\%20is\%20Social\%20Media_iCrossing_ebook.pdf. Accessed in March $8,2017$.

[15] M.E. Khouli, "The Most Important Negative Aspects of Using Social Networking Affecting the Family Stability in Abu Dhabi- A Pilo Study", in IACSIT International Journal of Engineering and Technology, Vol. 5 (1), February 2013, pp. 85-90.

[16] A. Abdulahi, B. Samadi, and B. Gharleghi, "A Study on the Negative Effects of Social Networking Sites Such as Facebook among Asia Pacific University Scholars in Malaysia”, in International Journal of Business and Social Science, vol. 5 (10), September 2014, pp.133-145.

[17] S.B. Baboo, A. Pandian, N.V. Prasad, and A. Rao, "Young People and New Media in Malaysia: An Analysis of Social Use and Practices" in ResearchersWorld - Journal of Arts, Science \& Commerce, vol. 4 (2), April 2013, pp. 50-56.

[18] S.C.Robinson, "Self-Disclosure and Managing Privacy: Implications for Interpersonal and Online Communication for Consumers and Marketers", in Journal of Internet Commerce, 2017, vol 16 (4), pp. 385 404.

[19] S. Waters, and J. Ackerman, "Exploring Privacy Management on Facebook: Motivations and Perceived Consequences of Voluntary Disclosure", in Journal of Computer-Mediated Communication, Vol. 17 2011, pp. 101-115

[20] S. Petronio, "Communication Privacy Management" in A First Look at Communication Thoery Eight Edition, E.M. Griffin (Eds). New York: Mc-Graw Hill, 2012, pp. 168-180.

[21] S.W. Littlejohn, K.A. Foss, and J.G. Oetzel, "Theories of Human Communication Eleventh Edition", Long Grove, IL: Waveland Press, Inc., 2017.

[22] D. Snape and L. Spencer, "The foundations of qualitative research". In Qualitative Research Practice, J. Ritchie \& J. Lewis. (Eds.). London: Sage Publications Ltd., 2003.

[23] B. Bungin, Penelitian Kualitatif: Komunikasi, Ekonomi, Kebijakan Publik, dan Ilmu Sosial Lainnya. Jakarta: Kencana, 2007.

[24] H.B. Sutopo, Metodologi Penelitian Kualitatif: Dasar Teori dan Terapannya dalam Penelitian, edisi kedua. Surakarta: UNS Press, 2006.

[25] E.P. McAloon, Management of Privacy Boundaries for People With Visible Disabilities, Thesis, Indiana University, 2014.

[26] A. Chennamaneni and A. Taneja, "Communication Privacy Management and Self-Disclosure on Social Media - A Case of Facebook", in Twentyfirst Americas Conference on Information Systems, Puerto Rico, 2015, pp. 1-11. 